Original scientific paper - Izvorni znanstveni rad

UDK: $636.2 / 637.12$

\title{
The soybean molasses in diets for dairy cows
}

doi: 10.15567/mljekarstvo.2017.0306

\begin{abstract}
Aleksandar Miletić ${ }^{1 *}$, Bojan Stojanovićn , Goran Grubićc ${ }^{2}$ Petar Stojićl , Mihailo Radivojevićl, Mirjana Joksimović - Todorovićc ${ }^{2}$, Mladen Popovac ${ }^{2}$, Saša Obradovićc ${ }^{3}$
\end{abstract}

\author{
${ }^{1}$ Institute PKB Agroekonomik, Industrijsko naselje bb, 11213 Belgrade, Serbia \\ ${ }^{2}$ University of Belgrade, Faculty of Agriculture, Nemanjina 6, 11080 Zemun, Serbia \\ ${ }^{3}$ State University of Novi Pazar, Vuka Karadžića bb, 36300 Novi Pazar, Serbia
}

Received - Prispjelo: 11.01.2017. Accepted - Prihvaćeno: 25.05.2017.

\begin{abstract}
The aim of this study was to investigate the effects of the use of soybean molasses in the nutrition of lactating cows on their performance and some blood and rumen content parameters. Treatments included isoenergetic and isoprotein rations: total mixed ration (TMR) which included $1 \mathrm{~kg}$ of soybean molasses and TMR without soybean molasses. The use of soybean molasses in TMR for lactating cows increased yield of $4 \%$ FCM (5.03 \%). There was no difference in milk fat content and yield between treatments. The use of soybean molasses increased the concentration ( 3.45 vs $3.32 \%$ ) and yield (from 0.81 to $0.88 \mathrm{~kg} / \mathrm{day}$ ) of milk protein. Improved utilization of consumed ration dry matter (DM), energy and crude protein by $4.60,4.81$ and $7.82 \%$, respectively, was confirmed. There was no significant effect of including soybean molasses in TMR on ruminal $\mathrm{pH}$ value, number and structure of protozoa population nor on their motility. Soybean molasses had a positive effect on decrease of the urea blood concentration (5.45 vs $6.30 \mathrm{mmol} / \mathrm{L}$ ) while no significant effects were observed for the concentrations of glucose, $\mathrm{Ca}$ and $\mathrm{P}$ in blood. Results of this study indicate that soybean molasses, as a source of readily available energy, can be used successfully in rations for lactating cows.
\end{abstract}

Key words: dairy cattle, nutrition, sugars, total mixed ration

\section{Introduction}

Carbohydrates are the most important source of energy in lactating cows ratios and account for $60-70 \%$ in ration total dry matter. Primary function of carbohydrates is to provide energy for rumen microorganisms and host animal (NRC, 2001). Fractions of carbohydrates vary considerably in the rate and final products of fermentation which further affects utilization of nutrients in animals (Oba, 2011).

Sugars are considered as fraction of carbohydrates which is being fermented very rapidly in rumen and in that way provides more fermentable energy for production of microbial proteins (Nocek and Russell, 1988; Oba et al., 2015). Degradation of sugars in rumen is complete and the rate of their fermentation ranges from 264 to $738 \% \mathrm{~h}^{-1}$ (Weisbjerg et al., 1998). Contrary to sugars, efficiency of degradation of starch in rumen is lower and depends on the way of processing the corn grain (NRC, 2001). Some authors report that rumen degradation of starch from rolled high moisture corn grain is $86.8 \%$ (Firkins et al., 2008) and $76.3 \%$ (Owens and Soderlund, 2006) while the rate of its fermentation ranges from 20 to $40 \% \mathrm{~h}^{-1}$ (Sniffen et al., 1992). Studies of some authors suggest that the rate of degradation of sugars and starch in rumen from high moisture corn grain is approximately the same being $0.40 \% \mathrm{~h}^{-1}$ and $0.35 \% \mathrm{~h}^{-1}$ (Lanzas et al., 2007). 
In optimally formulated rations sugars do not necessarily affect the decrease of $\mathrm{pH}$ value in rumen (Oba, 2011), they can increase the concentration of butyrate in rumen (Vallimont et al., 2004), to improve efficiency of nitrogen utilization (Sniffen et al., 1992) and to increase the content of protein in milk (Oba, 2011). A partial replacement of starch with sugars in the nutrition of high yielding dairy cows can often enhance the DM ration intake (Gao and Oba, 2015; Broderick and Radloff, 2004; Penner and Oba, 2009), the yield of energy-corrected milk (Gao and Oba, 2015) and the yield of milk fat (Penner and Oba, 2009).

In majority of rations the content of sugar is relatively low with the exception of by-products of sugar refineries (molasses, sugar beet pulp) and fresh grass. In previous studies there are almost no results regarding the effects of including the molasses obtained from soybean on production and physiological parameters in lactating cows. The effect of utilization of sugar beet molasses or sugarcane molasses in lactating cows rations was studied in a number of trials (Gao and Oba, 2015; Oba et al., 2015; Martel et al., 2011; Oba, 2011; Broderick and Radloff, 2004; Yan et al., 1997). Cows that consumed rations with molasses showed a tendency to increase the milk yield compared to cows which consumed ration with higher content of starch (G a o

Table 1. Chemical composition of soybean molasses

\begin{tabular}{cc}
\hline Item & $\begin{array}{c}\text { Concentration in DM, } \\
\mathrm{g} / \mathrm{kg}\end{array}$ \\
\hline $\mathrm{DM}, \mathrm{g} / \mathrm{kg}$ & 736.66 \\
\hline $\mathrm{CP}$ & 81.90 \\
\hline $\mathrm{NFC}$ & 800.70 \\
\hline $\mathrm{NDF}$ & 7.99 \\
\hline $\mathrm{ADF}$ & 4.00 \\
\hline $\mathrm{EE}$ & 7.10 \\
\hline $\mathrm{Ash}$ & 102.30 \\
\hline $\mathrm{Ca}$ & 3.50 \\
\hline $\mathrm{P}$ & 1.99 \\
\hline $\mathrm{pH}$ & 5.14 \\
\hline Energy value, & 7.74 \\
\hline $\mathrm{NE}_{\mathrm{L}} \mathrm{MJ} / \mathrm{kg} \mathrm{DM}$ &
\end{tabular}

DM: dry matter; CP: crude protein; NFC: non-fibre carbohydrates; NDF: neutral detergent fibre; ADF: acid detergent fibre; EE: ether extract; Ca: calcium; P: phosphorus and Oba, 2015; Martel et al., 2011). The researches of the effects of molasses supplemented rations on the milk fat and protein content gave different results. The results of several researches indicate a positive effect of including molasses into rations on the content of milk protein (Gao and Oba, 2015; Yan et al., 1997). As for a content of milk fat the results of researches (Martel et al., 2011; Oba, 2011; Penner and Oba, 2009; Yan et al., 1997) indicate that the use of molasses in lactating cows rations can increase the milk fat content while Siverson et al. (2014) state that molasses negatively affects the content and yield of milk fat.

Molasses can be a suitable feed for lactating cows as an ideal base for development and activity of rumen microorganisms. Protozoa in rumen convert sugar from molasses into glycogen accumulating in that way the reserves of carbohydrates in their cells (Hackmann and Firkins, 2015). Previous researches showed that total microbial accumulation of glycogen was increased with higher sugar content and that accumulated protozoal glycogen accounts for $51 \%$ of totally accumulated glycogen by rumen microbial population (Hall, 2011).

Important indicators of nutritional status of dairy cows can be blood biochemical and ruminal content parameters (Herdt et al., 2001).

Taking into account that there are almost no studies referring to the effect of use of soybean molasses for the nutrition of lactating cows the aim of conducted research was to examine the possibilities of utilization and effects of soybean molasses in rations for the lactating cows on some of their physiological and production parameters. On the basis of the results of this research the possibilities of including the soybean molasses into the rations for nutrition of lactating cows will be discussed.

\section{Material and methods}

\section{Animals and the diets}

The trial included 52 Holstein cows divided into two groups - control and experimental. There were 26 cows in each group and $80 \%$ animals were in the first and second lactation. The groups were equalized according to stage of lactation (86 and 92 days) and lactation in order (1.65 and 1.77), quantity of produced milk (27.75 and $28.12 \mathrm{~kg} /$ day) 
and body condition score (3.03 and 3.01). The trial was conducted on the commercial dairy cattle farm AD "Vojvodina" in Starčevo, Serbia. The cows were housed in the individual tie stalls with capacity of 120 cows.

The trial was set as one-factorial experimental arrangement where was determined the effect of ration (with soybean molasses and without soybean molasses) on milk yield and composition parameters and some blood biochemical and ruminal content parameters. A trial period lasted 60 days. Cows were fed with total mixed rations (TMR) which were equalised in protein and energy content (Table 2).
The forage part of the TMR was based on alfalfa hay and corn silage. Alfalfa hay (CP - $186 \mathrm{~g} / \mathrm{kg} \mathrm{DM}$, $\mathrm{NDF}$ - $\left.487.01 \mathrm{~g} / \mathrm{kg} \mathrm{DM}, \mathrm{NE}_{\mathrm{L}}-5.27 \mathrm{MJ} / \mathrm{kg} \mathrm{DM}\right)$ was obtained from the second cut, by harvesting the plants at the early bloom stage. A whole corn plant for ensiling was harvested at the $1 / 2$ milk line stage of maturity with $337 \mathrm{~g} / \mathrm{kg}$ dry matter content. Ensiling was carried out in horizontal silo, with the use of inoculant Biomin ${ }^{\circledR}$ (BioStabil). Corn silage (CP - $75.01 \mathrm{~g} / \mathrm{kg} \mathrm{DM}, \mathrm{NDF}-467 \mathrm{~g} / \mathrm{kg} \mathrm{DM}$, $\mathrm{NE}_{\mathrm{L}}-6.10 \mathrm{MJ} / \mathrm{kg} \mathrm{DM}$ ) characterized with $\mathrm{pH}$ value of 4.02 and concentrations of lactic and acetic acid were $8.49 \mathrm{~g} / \mathrm{kg}$ and $5.91 \mathrm{~g} / \mathrm{kg}$, respectively.

Table 2. Composition and nutritional value of the TMRs for lactating cows

\begin{tabular}{|c|c|c|}
\hline Ingredients, $\mathrm{kg} \mathrm{DM} /$ day & Experimental group & Control group \\
\hline Alfalfa hay & 4.25 & 4.25 \\
\hline Corn silage & 7.08 & 7.08 \\
\hline High moisture corn grain & 1.91 & 2.54 \\
\hline Soybean molasses & 0.74 & - \\
\hline Corn grain & 1.94 & 1.94 \\
\hline Sunflower meal & 1.10 & 1.10 \\
\hline Soybean meal & 1.07 & 1.07 \\
\hline Soybean cake & 1.11 & 1.11 \\
\hline Wheat bran & 1.08 & 1.08 \\
\hline Vitamin - mineral mix ${ }^{1}$ & 0.12 & 0.12 \\
\hline Monocalcium phosphate & 0.08 & 0.08 \\
\hline Limestone & 0.12 & 0.12 \\
\hline Salt & 0.12 & 0.12 \\
\hline $\mathrm{DM}, \mathrm{kg}$ & 20.72 & 20.61 \\
\hline $\mathrm{CP}, \mathrm{g} / \mathrm{kgDM}$ & 160.0 & 160.60 \\
\hline RDP, g/kgDM & 108.0 & 107.0 \\
\hline RUP, g/kgDM & 52.0 & 53.60 \\
\hline $\mathrm{NDF}, \mathrm{g} / \mathrm{kgDM}$ & 357.0 & 367.0 \\
\hline $\mathrm{ADF}, \mathrm{g} / \mathrm{kgDM}$ & 213.0 & 218.0 \\
\hline Forage NDF, g/kgDM & 259.0 & 261.0 \\
\hline NFC, g/kgDM & 410.60 & 400.70 \\
\hline $\mathrm{EE}, \mathrm{g} / \mathrm{kgDM}$ & 34.0 & 35.0 \\
\hline Ash, g/kgDM & 38.40 & 36.70 \\
\hline $\mathrm{Ca}, \mathrm{g} / \mathrm{kgDM}$ & 7.0 & 7.0 \\
\hline $\mathrm{P}, \mathrm{g} / \mathrm{kgDM}$ & 5.0 & 5.0 \\
\hline Energy value $\mathrm{NE}_{\mathrm{L}} \mathrm{MJ} / \mathrm{kg} \mathrm{DM}$ & 6.65 & 6.65 \\
\hline
\end{tabular}

${ }^{1}$ Mixture of vitamins and trace elements, 1 kg contains: Vitamin A - 1000 IU, Vitamin D - 150 IU, Vitamin E - 4000 IU, Mg - 86 g, S - 43 g, Fe - 3000 mg, Cu - 600 mg, Mn - 4000 mg, Zn - 3000 mg, J - 60 mg, Se - 10 mg, and Co - 10 mg.

DM: dry matter; CP: crude protein; RDP: rumen-degradable protein; RUP: rumen-undegradable protein NDF: neutral detergent

fibre; ADF: acid detergent fibre; NFC: non-fibre carbohydrates; EE: ether extract; Ca: calcium; P: phosphorus 
The cows were offered TMR two times a day at 06:00 and 12:00. Cows in the experimental group were offered a TMR that contained $1 \mathrm{~kg}$ of soybean molasses while the ration for cows in control group did not contain soybean molasses. Isoenergetic ration was supplied by a higher content of silage of high moisture corn grain in TMR for the control group. High moisture corn grain containing $636 \mathrm{~g} / \mathrm{kg}$ dry matter was ensiled in horizontal silo by using of inoculant Biomin ${ }^{\circledR}$ (BioStabil). High moisture corn grain silage (CP - $76.01 \mathrm{~g} / \mathrm{kg} \mathrm{DM}, \mathrm{NDF}-$ $263 \mathrm{~g} / \mathrm{kg} \mathrm{DM}, \mathrm{NE}_{\mathrm{L}}-7.82 \mathrm{MJ} / \mathrm{kg} \mathrm{DM}$ ) had $\mathrm{pH}$ value of 4.45 , while the concentrations of lactic and acetic acid were $10.5 \mathrm{~g} / \mathrm{kg}$ and $2.09 \mathrm{~g} / \mathrm{kg}$, respectively. Rations were formulated for the cows $650 \mathrm{~kg}$ BW with milk production of $29 \mathrm{~kg} /$ day, containing $3.6 \%$ milk fat and $3.4 \%$ protein by using of NRC (2001) model and program package.

Soybean molasses was provided from the soybean processing factory "Soja protein", Bečej, where it was obtained as a by-product in the production of soybean protein concentrate. Soybean molasses was obtained after the treatment - soaking defatted soybean by diluted ethanol ( $66 \%$ ) at $70{ }^{\circ} \mathrm{C}$, after which the obtained mixture of water, ethanol and dissolved sugars released ethanol and water in the process of distillation while by vaporisation $\left(90^{\circ} \mathrm{C}\right)$ sugar solution gets concentrated.

\section{Analytical procedure}

Chemical analysis of soybean molasses was done in SP Laboratory of AD Bečej in Bečej, and chemical analysis of high-moisture corn grain silage in the Laboratory for quality management EKO - LAB DOO in Belgrade. Other feedstuffs and TMRs were analysed in the Laboratory for the animal nutrition at the Faculty of Agriculture - Belgrade. For determination of dry matter and further chemical analysis the TMR samples were collected twice weekly during trial period. Collected samples were immediately frozen $\left(-20^{\circ} \mathrm{C}\right)$ and stored for analysis. The samples of corn silage, high-moisture corn grain silage and TMRs were dried at $55^{\circ} \mathrm{C}$ in a forced - air oven for 48 hours. Analytical DM content of oven - dried samples and concentrate diet ingredients were determined by drying at $105^{\circ} \mathrm{C}$ for 5 hours. The samples were ground through $1 \mathrm{~mm}$ diameter sieve. Crude protein was obtained by the Kjeldahl method (method 988.05; AOAC, 2002). Neutral detergent fibres (NDF) were obtained according to the method of Van Soest by use of thermostabile $\alpha$-amylase (A3306 Sigma Chemical Co., St Louis, MO, USA), (method 2002:04, AOAC, 2002). Acid detergent fibres (ADF) were obtained by the Van Soest method (method 973.18, AOAC, 2002) and ether extract was obtained by the Soxhlett method (method 920.39; AOAC, 2002). Ash contents were determined by combustion at $550{ }^{\circ} \mathrm{C}$ for $6 \mathrm{~h}$. Calcium and phosphorus were determined according to the AOAC methodology (2002), (method 935.13; 964.06).

\section{Milk yield and composition}

During the experimental period the milk yield and chemical composition (content of milk fat and milk protein) was determined at 20 days interval. Cows were milked twice a day (at 06:00 and 18:00). Milk was sampled according to the internationally agreed principles (ICAR, 2005), by using the milk meter Waikato MK V, company Waikato Milking Systems NZ Ltd., the sample being a proportional part of total milk quantity ( $25 \mathrm{~g} / \mathrm{kg}$ milk). Milk chemical composition (content of milk fat and protein) was analysed by infrared spectroscopy using the Milco Scan S 50 apparatus (Foss Electric, Hillerod, Denmark) in laboratory at the Faculty of Agriculture - Novi Sad.

\section{Blood biochemical and rumen parameters}

For the purpose of determining concentration of analyzed parameters the blood sampling was performed at the end of trial. Blood was taken by caudal vein puncturing (v. coccigea), approximately three hours after morning feeding. By centrifugation of a whole blood sample the blood serum was obtained and analyzed by standard biochemical analysis in laboratory for diagnostic analysis of PKB Corporation - Centre for livestock production, Belgrade. The values for concentrations of glucose, urea, calcium and phosphorous were determined. Concentration of glucose in blood was determined by use of Precision Xtra Plus device (Abbott Laboratories). The concentration of calcium was determined by $\mathrm{O}$ - Kresolphthalein method (Sarkar and Chanhan, 1967) and the concentration of inorganic phosphate by UV method (Tietz, 1983). Concentration of urea in blood was determined by enzyme kinetic method (Tietz, 1986). 
At the end of trial rumen content was examined as well. The rumen content was collected by using the ruminal tube-like probe and samples were taken three hours after morning feeding. In the analysis of liquid content of rumen, $\mathrm{pH}$ value was determined by use of digital $\mathrm{pH}$-meter ( $\mathrm{pH}$ Testo 206 - pH2) while the number and motility of large, medium and small infusories was determined by using of a light microscope (Neelesh and Upadhyay, 2009; Cockcroft and Scott, 2015).

\section{Calculation and statistical analysis}

The experiment was designed as one factorial arrangement with two treatments. Statistical processing of obtained results was performed by use of PASW Statistics 18 software (SPSS Inc, 2016) computer programme. Differences among treatment means were tested for significance using Student $t$-test. Statistical significance was determined at the $(\mathrm{P}<0.05)$ and $(\mathrm{P}<0.01)$ levels of significance.

\section{Results and discussion}

The TMR which included soybean molasses provided a higher milk yield by $4.94 \%(\mathrm{P}<0.05)$ and a higher yield of $4 \%$ FCM by $5.03 \%(P<0.05)$ relative to ratio without soybean molasses (Table 3 ).

Use of soybean molasses in the nutrition of lactating dairy cows increases the concentration of readily degradable fractions of carbohydrates providing the energy for microbial activity and stimulates the synthesis of microbial protein in rumen which has a positive effect on milk yield. Vallimont (2004) reported that increased rate of readily degradable fractions of carbohydrates in rumen can positively affect the synthesis of microbial protein and milk yield. An optimal portion for molasses in diets for lactating cows is up to $3 \% \mathrm{DM}$ which has a positive effect on milk yield (Broderick and Radloff, 2004). These authors investigated the effects of molasses supplementation in the concentrations of $0,3,6$ and $9 \% \mathrm{DM}$ where obtained milk yields were 43.6, 45.5, 44.0 and $42.4 \mathrm{~kg} /$ day, respectively. Increased content of molasses in lactating cows rations (from 125 to $370 \mathrm{~g} /$ day) increases the quantity of produced milk (from 15.5 to $17.6 \mathrm{~kg} /$ day) (Yan et al., 1997). Cows fed rations containing more of disaccharides achieved higher milk yield in comparison with the cows fed rations with higher content of starch (G ao and Oba, 2015). The results of our research differ from the conclusions of Martel et al. (2011) where corn grain was substituted by the sugarcane molasses in the rations for dairy cows in the quantity of 2.5 and $5 \% \mathrm{DM}$ and decrease of the milk yield by 1.9 and $5.6 \%$ were found, respectively, with no significant effect on $4 \%$ FCM yield. Sivers on et al. (2014) reported that increased content of sugarcane molasses in ration for lactating cows (from 2.9 to $5.8 \% \mathrm{DM}$ ) had no positive effect on milk production (34.9 and $34.4 \mathrm{~kg} /$ day).

There were no significant effects of soybean molasses addition in TMR on the content and yield of milk fat (Table 3). The our results differ from the conclusions of Yan et al. (1997) who reported that increase of the content of molasses in the lactating

Table 3. The effect of soybean molasses in lactating cows nutrition on milk yield and chemical composition (mean $\pm \mathrm{SD}$ )

\begin{tabular}{cccccc}
\hline Parameter & $\begin{array}{c}\text { Diet with } \\
\text { soybean molasses }\end{array}$ & SEM & $\begin{array}{c}\text { Diet without } \\
\text { soybean molasses }\end{array}$ & SEM & $p$ value \\
\hline Milk yield, kg/day & $25.68 \pm 4.09$ & 0.40 & $24.47 \pm 4.17$ & 0.41 & $0.036^{*}$ \\
\hline $4 \%$ FCM yield, kg/day & $24.20 \pm 4.01$ & 0.39 & $23.04 \pm 4.22$ & 0.41 & $0.044^{*}$ \\
\hline Milk fat concentration, \% & $3.62 \pm 0.37$ & 0.04 & $3.60 \pm 0.35$ & 0.03 & $0.811^{\mathrm{ns}}$ \\
\hline Milk fat yield, kg/day & $0.93 \pm 0.17$ & 0.02 & $0.88 \pm 0.18$ & 0.02 & $0.063^{\mathrm{ns}}$ \\
\hline Milk protein concentration, \% & $3.45 \pm 0.38$ & 0.04 & $3.32 \pm 0.30$ & 0.03 & $0.006^{* *}$ \\
\hline Milk protein yield, kg/day & $0.88 \pm 0.17$ & 0.02 & $0.81 \pm 0.16$ & 0.02 & $0.002^{* *}$ \\
\hline Milk fat : protein ratio & 1.06 & - & 1.07 & - & - \\
\hline
\end{tabular}

${ }^{*}$ Statistical significance $(\mathrm{P}<0.05) ;{ }^{*}$ Statistical significance $(\mathrm{P}<0.01)$; ns - non significant $(\mathrm{P}>0.05)$ 
cows rations increases the concentration of milk fat. Martel et al. (2011) determined that replacing corn grain by sugar beet molasses in quantity of $5 \%$ in DM of rations for lactating cows increases the content of milk fat by $13.6 \%$ but the effect on the yield of milk fat was not observed. Increase of the concentration of molasses in the dairy cows ration (from 2.9 to $5.8 \%$ ) can decrease milk fat concentration (from 3.16 to $2.64 \%$ ) and yield (from 1.20 to $0.79 \mathrm{~kg} /$ day) (Siverson et al., 2014).

The cows fed soybean molasses supplemented ration had a higher milk protein concentration and yield relative to cows from control group (3.92 and $8.64 \%$, respectively $),(\mathrm{P}<0.01)$. By including soybean molasses into ration the portion of readily degradable fractions of carbohydrates in rumen increases, which is likely to contribute to better energy supply of microorganisms and consequently higher rate of microbial protein synthesis from available non-protein nitrogen. The cows fed with rations containing higher level of disaccharides had higher concentration and yield of milk protein compared to cows fed rations with higher content of starch ( 3.51 vs $3.46 \%$; 1.32 vs $1.28 \mathrm{~kg} /$ day), (Oba and Gao, 2015). On the contrary, Martel et al. (2011) concluded that substituting the corn grain with sugar beet molasses in the quantity of $5 \% \mathrm{DM}$ of ration decreased protein milk yield by $0.05 \mathrm{~kg} /$ day but the effect on protein concentration (3.32 vs $3.31 \%$ ) was not observed.

Table 4. The effect of soybean molasses on a feed conversion ratio in lactating dairy cows

\begin{tabular}{ccc}
\hline Feed conversion ratio & $\begin{array}{c}\text { Diet with } \\
\text { soybean } \\
\text { molasses }\end{array}$ & $\begin{array}{c}\text { Diet } \\
\text { without } \\
\text { soybean } \\
\text { molasses }\end{array}$ \\
\hline $\mathrm{DM}, \mathrm{kg} / \mathrm{kg}$ milk & 0.83 & 0.87 \\
\hline $\mathrm{DM}, \mathrm{kg} / \mathrm{kg} 4 \% \mathrm{FCM}$ & 0.88 & 0.93 \\
\hline $\mathrm{OM}, \mathrm{kg} / \mathrm{kg}$ milk & 0.68 & 0.72 \\
\hline $\mathrm{OM}, \mathrm{kg} / \mathrm{kg} \mathrm{4} \% \mathrm{FCM}$ & 0.73 & 0.77 \\
\hline Energy, MJ NE $/ \mathrm{kg}$ milk & 5.54 & 5.82 \\
\hline Energy, $\mathrm{MJ} \mathrm{NE} / \mathrm{kg} 4 \% \mathrm{FCM}$ & 5.88 & 6.18 \\
\hline $\mathrm{CP}, \mathrm{kg} / \mathrm{kg} \mathrm{CP}$ milk & 3.77 & 4.09 \\
\hline $\mathrm{CP}, \mathrm{kg} / \mathrm{kg} \mathrm{CP} 4 \% \mathrm{FCM}$ & 4.01 & 4.36 \\
\hline
\end{tabular}

DM: dry matter; OM: organic matter; FCM: $4 \%$ fat - corrected milk calculated as $(0.4 \mathrm{x} \mathrm{kg} \mathrm{milk)} \mathrm{+} \mathrm{(15} \mathrm{x} \mathrm{kg} \mathrm{milk} \mathrm{fat);}$ CP: crude protein.
A positive effect of use of soybean molasses on the feed conversion ratio was determined in the trial. The results of the research indicate that cows fed ration with soybean molasses utilized DM and organic matter (OM) of the ration more efficiently by 4.60 and $5.56 \%$ for milk production, i.e. by 5.38 and $5.19 \%$ for the production of $4 \%$ FCM, respectively. Similar was observed regarding the efficiency of energy and CP utilization. Namely, cows in experimental group used energy more efficiently from consumed diet by 4.81 and $4.85 \%$ for milk and for $4 \%$ FCM yield, respectively. Improvement in the efficiency of utilization of consumed protein was 7.82 and $8.03 \%$ for milk and $4 \%$ FCM production (Table 4). Obtained results differ from the conclusions of Martel et al. (2011) where corn grain was replaced by sugarcane molasses in the quantity of 2.5 and $5 \% \mathrm{DM}$ of ration for lactating cows with determined decreased efficiency of ration DM utilization by 2.9 and $5.8 \%$, and reduced efficiency of protein utilization by 3.04 and $4.97 \%$. Siverson et al. (2014) evaluated the effect of using the sugarcane molasses in concentration of 0-5.8 \% DM and determined no significant effect on feed conversion for milk production. On the other hand these authors determined decreased utilization of protein with increased content of sugarcane molasses in lactating cow rations by $1.5-7.4 \%$.

Among blood biochemical parameters the concentrations of glucose, urea, calcium and phosphorous were analyzed. The concentrations of all mentioned parameters were within the range of physiological limits (Rodostitis et al., 2007). Cows fed ratios containing soybean molasses had somewhat lower concentration of glucose in blood (3.05 mmol/L) compared to cows which did not consume soybean molasses (3.26 mmol/L) but differences were not significant (Figure 1). Somewhat lower concentration of glucose observed in experimental group may be a consequence of consuming the diet in which existing ratio of carbohydrates fractions (with different rate of ruminal degradation) contributed to a change in molar concentration of volatile fatty acids, that could be a physiological prerequisite of a lower glycaemia. Partial substitution of starch by molasses sugars in lactating cows ration decreases molar proportion of propionate in rumen content (Martel et al., 2011) or it remains 
unchanged (Vallimont et al., 2004) which results in somewhat lower concentration of glucose in plasma. Results obtained in our research differ from the conclusions of Moloney et al. (1994), who determined a lower concentration of glucose in blood of cows fed ration with higher content of starch in comparison with the cows fed molasses supplemented rations (3.44: $3.55 \mathrm{mmol} / \mathrm{L})$.

The blood urea concentration differed $(\mathrm{P}<0.01)$ between groups. The lower value $(5.45 \mathrm{mmol} / \mathrm{L})$ was found for the experimental group compared with the blood urea concentration of the control group (6.30 $\mathrm{mmol} / \mathrm{L})$. Using of soybean molasses in the nutrition of lactating cows increases the readily available energy necessary for the microbial synthesis of protein in rumen, on the basis of non-protein nitrogen, resulting in decrease of urea concentration in blood plasma. Gao and Oba (2015) determined that partial substitution of corn grain by molasses sucrose in dairy cows ration can increase ruminal fermentation of $\mathrm{OM}$ and synthesis of microbial protein using ammonia nitrogen that consequently leads to decrease of concentration of urea in blood. The cows fed ratio with higher content of starch had higher concentration of urea in plasma than animals fed ration containing molasses (5.56 vs $4.24 \mathrm{mmol} / \mathrm{L}$ ), (Moloney et al., 1994).

A slightly lower concentration of $\mathrm{Ca}$ and $\mathrm{P}$ in blood was determined $(2.76$ and $2.54 \mathrm{mmol} / \mathrm{L}$, respectively) in cows fed soybean molasses supplemented ration than in the control group (2.85 and $2.68 \mathrm{mmol} / \mathrm{L}$, respectively) although determined differences between groups were not significant.

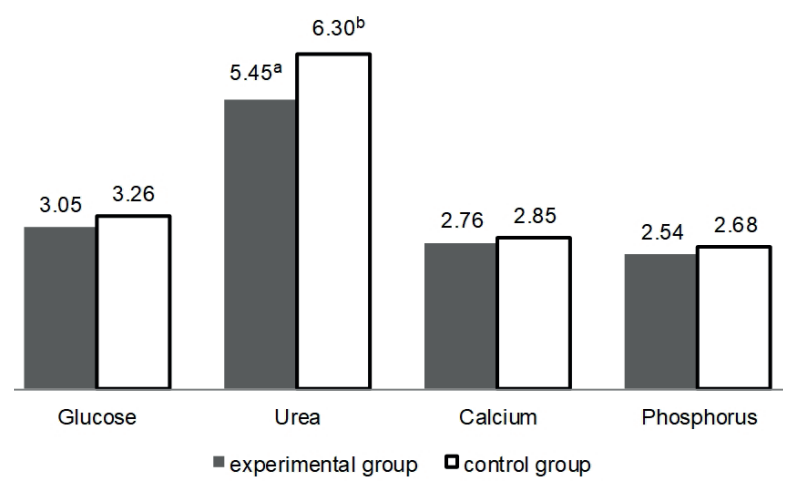

Figure 1. Values for blood biochemical parameters of dairy cows fed diet with or without soybean molasses, mmol/L. a,bValues with different superscripts differ $(\mathrm{P}<0.01)$
The results of the analysis of ruminal $\mathrm{pH}$ value as well as number of protozoa in ruminal content are shown in Figure 2.

The $\mathrm{pH}$ value of rumen content in both groups was within the range of optimal values (Cockcroft and Scott, 2015). Namely, cows fed ration with soybean molasses had somewhat lower rumen $\mathrm{pH}$ value (6.87) compared with cows of control group whose rumen $\mathrm{pH}$ value was a bit higher (7.05) but differences were not significant. Somewhat lower $\mathrm{pH}$ value in experimental group can be contributed to higher rate of hydrolysis and fermentation of soybean molasses sugars in rumen relative to starch. Use of molasses in the nutrition of dairy cows can result in the increase of molar proportion of butyric acid in rumen (Vallimont et al., 2004) which stimulates blood flow through rumen epithelium and enhances the capacity of absorption of volatile fatty acids from epithelial cells into bloodstream that leads to the increase of ruminal pH value (Martel et al., 2011). Gao and Oba (2015) reported that the cows fed diets higher in sugar content had lower ruminal $\mathrm{pH}$ value compared with the cows fed diets with higher content of starch (6.19:6.23). Martel et al. (2011) substituted the corn grain with sugarcane molasses and determined the increase of ruminal $\mathrm{pH}$ value (5.73 : 5.87). Broderick and Radloff (2004) found that increase in the content of sugar beet molasses in ration DM for lactating cows (from 3 to $9 \%$ ) leads to higher ruminal $\mathrm{pH}$ value $(5.90: 6.06)$.

The number of small, medium and large protozoa did not differ $(\mathrm{P}>0.05)$. Unlike to small and medium protozoa whose number was more equable

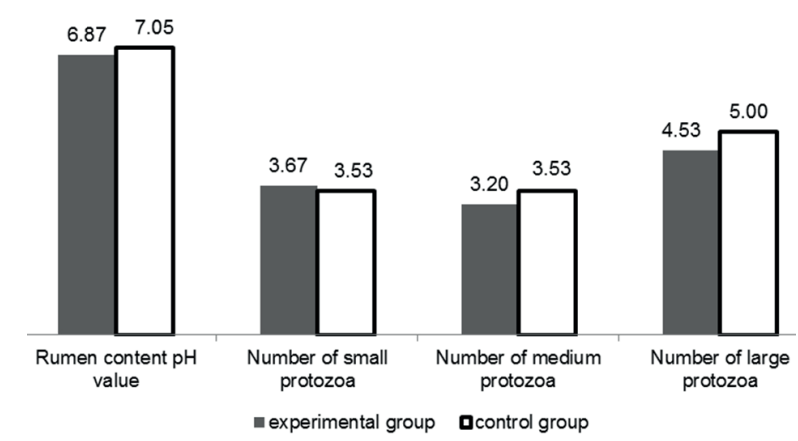

Figure 2. Results of the analysis of rumen content - $\mathrm{pH}$ value and number of protozoa $\left(\mathrm{x} 10^{5}\right.$ $\mathrm{mL}^{-1}$ ) of lactating cows fed diet with or without soybean molasses 
for in both groups of cows, the number of large protozoa was somewhat increased in cows fed rations with higher content of starch. Increase of the content of starch consequently leads to increase in number of large protozoa considering that large protozoa primarily use starch (Jouany and Ushida, 1999). According to Martel et al. (2011) there was no additional effect on dominant ruminal protozoa of added sugar in high concentrate cattle diets, while the use of sugar in dominantly forage diets had positive effect on protozoa growth.

Like in the number of protozoa a similar tendencies were determined also for protozoa motility. Namely, a differences $(\mathrm{P}>0.05)$ regarding motility of infusories between experimental and control group of cows (2.60 vs 2.67) were determined (0 to 3 scale).

\section{Conclusions}

The soybean molasses can be used successfully in the rations for high - yielding dairy cows, primarily as a source of readily available energy in rumen, as it contributes to increased production of milk and content of milk protein. A significant effect of soybean molasses on the content of milk fat was not determined. Including the soybean molasses in the ration may enhance a quantity of readily available energy and provide more effective utilization by rumen microorganisms and host animal. The use of soybean molasses in the diet for lactating cows has a positive effect on decrease of the concentration of urea in blood, while there was no significant effect on ruminal $\mathrm{pH}$ value and on the number and structure of protozoa population.

\section{Acknowledgment}

The authors wish to express their gratitude to the AD "Soja Protein" - Bečej, SP laboratory in Bečej, Laboratory for the animal nutrition at the Faculty of Agriculture of the University in Belgrade, Laboratory for diagnostic research of PKB Corporation in Belgrade, Laboratory for quality management EKO - LAB DOO in Belgrade and Laboratory for the animal nutrition at the Faculty of Agriculture of the University in Novi Sad for their support in carrying out this research.

\section{Sojina melasa u obrocima krava u laktaciji}

\section{Sažetak}

Provedeno istraživanje imalo je za cilj ispitati utjecaj korištenja sojine melase $\mathrm{u}$ hranidbi krava $\mathrm{u}$ laktaciji na proizvodne rezultate i važnije pokazatelje metaboličkog profila. Korišteni su izoenergetski i izoproteinski obroci: TMR koji je uključio $1 \mathrm{~kg}$ sojine melase i TMR bez sojine melase. Korištenje sojine melase u TMR-u za krave u laktaciji statistički je značajno $(\mathrm{P}<0,05)$ utjecalo na povećanje prinosa $4 \%$ MKM (5,03 \%). Razlike u prosječnom udjelu i prinosu mliječne masti između tretmana nisu bile statistički značajne. Korištenje sojine melase statistički značajno $(\mathrm{P}<0,01)$ povećava udjel $(3,45$ vs $3,32 \%$ ) i prinos (sa 0,81 na $0,88 \mathrm{~kg} / \mathrm{dan}$ ) proteina mlijeka. Utvrđeno je poboljšanje iskorištavanja konzumirane suhe tvari obroka, energije i sirovog proteina za 4,60, 4,81 i 7,82 \%. Nije bilo značajnog utjecaja uključivanja sojine melase u TMR na ruminalnu $\mathrm{pH}$ vrijednost, brojnost i strukturu protozoa, kao niti na njihovu pokretljivost. Sojina melasa imala je značajan pozitivan učinak $(\mathrm{P}<0,01)$ na smanjenje koncentracije uree $\mathrm{u}$ krvi $(5,45$ vs $6,30 \mathrm{mmol} / \mathrm{L}$ ), pri čemu nije bilo značajnih učinaka na koncentraciju glukoze, Ca i P u krvi. Rezultati ovog istraživanja ukazuju da se sojina melasa, kao izvor lako dostupne energije, može uspješno koristiti u obrocima krava u laktaciji.

\section{Ključne riječi: krave u laktaciji, hranidba, šećeri, TMR}

\section{References}

1. AOAC International. 2002. Official Methods of Analysis. $17^{\text {th }}$ ed. AOAC International, Arlington, VA. ISSN: 1944-7922

2. Broderick, G.A. and Radloff, W.J. (2004): Effect of molasses supplementation on the production of lactating dairy cows fed diets based on alfalfa and corn silage. Journal of Dairy Science 87 (9), 2997-3009. https://doi.org/10.3168/jds.S0022-0302(04)73431-1

3. Cockcroft, P.D., Scott, P. (2015): Special diagnostic procedures. Bovine Medicine 3, 136. ISBN: 978-1-44433643-6 
4. Firkins, J.L., Oldick, B.S., Pantoja, J., Reveneau, C., Gilligan, L.E., Carver, L. (2008): Efficacy of liquid feeds varying in concentration and composition of fat, nonprotein nitrogen, and nonfiber carbohydrates for lactating cows. Journal of Dairy Science 91, 1969-1984. https://doi.org/10.3168/jds.2007-0868

5. Gao, X., Oba, M. (2015): Effect of increasing dietary nonfiber carbohydrate with starch, sucrose, or lactose on rumen fermentation and productivity of lactating dairy cows, Journal of Dairy Science 99, 291-300. http://dx.doi.org/10.3168/jds.2015-9871

6. Hall, M.B. (2011): Isotrichid protozoa influence conversion of glucose to glycogen and other microbial products. Journal of Dairy Science 94, 4589-4602. https://doi.org/10.3168/jds.2010-3878

7. Hackmann, T.J., Firkins, J.L. (2015): Maximizing efficiency of rumen microbial protein production. Frontiers in Microbiology 6, 1-16. https://doi.org/10.3389/fmicb.2015.00465

8. Herdt, T.H., Dart, B., Neuder, L. (2001): Will large dairy herds lead to the revival of metabolic profile testing? American Associatio of Bovine Practition 34, 27-34

9. Jouany, J.P., Ushida, K. (1999): The Role of Protozoa in Feed Digestion. Asian-Australasian Journal of Animal Sciences 12 (1), 113-128. https://doi.org/10.5713/ajas.1999.113

10. Lanzas, C., Sniffen, C.J., Seo, S., Todeschi, L.O., Fox, D.G. (2007): A revesed CNCPS feed carbohydrate fractionation sheme for formulating rations for ruminants. Animal Feed Science and Tehnology 136, 167-190. http://dx.doi.org/10.1016/j.anifeedsci.2006.08.025

11. Lee, M.R.F., Merry, R.J., Davies, D.R., Moorby, J.M., Humphreys, M.O., Theodorou, M.K., MacRae, J.C., Scollan, N.D. (2003): Effect of increasing availability of water-soluble carbohydrates on in vitro rumen fermentation. Animal Feed Science and Technology, 104, 59-70. http://dx.doi.org/10.1016/S0377-8401(02)00319-X

12. Martel, C.A., Titgemeyer, E.C., Mamedova, L.K., Bradford, B.J. (2011): Dietary molasses increases ruminal $\mathrm{pH}$ and enhances ruminal biohydrogenation during milk fat depression. Journal of Dairy Science 94, 3995-4004. http://dx.doi.org/10.3168/jds.2011-4178

13. Moloney, A.P., Almiladi, A.A., Drennan, M.J., Caffrey, P.J. (1994): Rumen and blood variables in steers fed grass silage and rolled barley or sugar cane molasses-based supplements. Animal Feed Science and Technology 50, 37-54. http://dx.doi.org/10.1016/0377-8401(94)90008-6

14. Neelesh, S., Upadhyay, S.R. (2009): Clinical Veterinary Medicine, Division of Veterinary Medicine \& Jurisprudence Faculty of Veterinary Sciences \& Animal Husbandry Sher - $e$ - Kashmir University of Agricultural Sciences \& Technology R.S. Pura, Jammu - 181102 (J\&K), India. ISBN: $9788190851251(\mathrm{HB})$

15. Nocek, J.E., Russell, J.B (1988): Protein and energy as an integrated system. Relationship of ruminal protein and carbohydrate availability to microbial sythesis and milk production. Journal of Dairy Science 71, 2070-2107. http://dx.doi.org/10.3168/jds.S0022-0302(88)79782-9

16. Nutrient Requirements of Dairy Cattle: Seventh Revised Edition (2001). doi: https://books.google.rs/ books?ISBN=030951521 1
17. Oba, M. (2011): Review: Effects of feeding sugars on productivity of lactating dairy cows. Canadian Journal of Animal Science 91 (1), 37-46. https://doi.org/10.4141/CJAS10069

18. Oba, M., Mewis, J.L., Zhining, Z. (2015): Effects of ruminal doses of sucrose, lactose and corn starch on ruminal fermentation and expression of genes in ruminal epithelial cells. Journal of Dairy Science 98, 586-594. http://dx.doi.org/10.3168/jds.2014-8697

19. Owens, F., Soderlund, S. (2006): Ruminal and postruminal Starch digestion by cattle. In: Proc. of Cattle Grain Processing Synposium, Stillwater, OK. Oklahoma State University, Stillwater, pp. 116-128. http://beefextension.com/files/proceedings\%20final.pdf

20. Penner, G.B., Oba, M. (2009): Increasing dietary sugar concentration may improve dry matter intake, ruminal fermentation, and productivity of dairy cows in the postpartum phase of the transition period. Journal of Dairy Science 92, 3341-3353. http://dx.doi.org/10.3168/jds.2008-1977

21. Rodostitis, O.M., Gay, C.C., Blood, D.C., Hinchkliff, K.W., Constable, P.D. (2007): Rumen acidosis. Veterinary Medicine 10, 314-325.

22. Sarkar, R.B.C., Chanhan, U.P.S. (1967): Analytical Biochemistry 10, 155. https://doi.org/10.1016/0003-2697(67)90273-4

23. Siverson, A., Vargas-Rodriguez, C.F., Bradford, B.J. (2014): Effects of molasses products on productivity and milk fatty acid profile of cows fed diets high in dried distillers grains with soluble. Journal of Dairy Science 97, 3860-3865. https://doi.org/10.3168/jds.2014-7902

24. Sniffen, C.J., O'Connor, J.D., Van Soest, P.J., Fox, D.G, Russell, J.B. (1992): Net carbohydrate and protein system for evaluating cattle diets: II carbohydrate and protein availability. Journal of Animal Science 70, 3562-3577. https://doi.org/10.2527/1992.70113562x

25. SPSS Inc (2016): PASW Statistics 18 software. Demo version of software. https://www.spss.com/Registration/premium/consol056.cfm?Demo_id $=37$

26. Tietz, N. (1983): Clinical Guide to Laboratory Tests. 384. W.B. Saunders Company, Philadelphia. 5, 384.

27. Tietz, N. (1986): Textbook of Clinical Chemistry. W.B. Saunders Company, Philadelphia. https://doi.org/10.1016/0307-4412(86)90182-2

28. Vallimont, J.E., Bargo, F., Cassidy, T.W., Luchini, N.D., Broderick, G.A., Varga, G.A. (2004): Effects of replacing dietary starch with sucrose on ruminal fermentation and nitrogen metabolism in continuous culture. Journal of Dairy Science 87, 4221-4229. http://dx.doi.org/10.3168/jds.S0022-0302(04)73567-5

29. Weisbjerg, M.R., Hvelplund, T., Bibby, B.M. (1998): Hydrolysis and fermentation rate of glucose, sucrose and lactose in the rumen. Acta Agriculturae Scandinavica Animal Science 48, 12-18. ISSN: 0906-4702 https://doi.org/10.1080/09064709809362398

30. Yan, T., Roberts, D.J., Higgibothan, J. (1997): The effect of feeding high concentrations of molasses and supplementing with nitrogen and unprotected tallow on intake and performance of dairy cows, Animal Science 64 (1), 17-24. https://doi.org/10.1017/S1357729800015514 